\title{
ANOMALIEE IN DIE GESKIEDENIS VAN DIE GRIEKSE WYSBEGEERTE
}

Die geskiedskrywing van die wysbegeerte is sowel 'n saak van historiese aanvoeling as van metodologiese geskooldheid. Sistematies aangelegde wysgere kan selde meer as 'n rasionalistiese maakwerk van die geskiedenis tot stand bring by gebrek aan daardie aanvoelingsvermoë wat enkel in 'n beperkte mate leerbaar is. 'n Mens besit daardie gawe of besit dit nie, net soos vir die een verstand vir die logika en vir die ander een vir die etiek voorbestem is. Daarom is 'n bepaalde ,genia liteit" (die woord in etimologiese sin, nie in aksiologiese sin opgevat nie) 'n algemene voorvereiste om die lewe, ook die lewe van gedagtes te rekonstrueer. Gedagtes leef immers in die gees van mense en nie daarbuite as selfstandige wesens nie, en mense is voorasnog nie elektroniese masjienes, rasionalistiese of wiskundige deduksies of rasionalistiese formules nie. Daarbenew'ens veronderstel die geskiedenis ook metode, en metode is op sy beurt nie iets wat 'n mens somaar uit 'n pocket-boekie kan leer nie, maar wat spontaan uit die persoonlike lewens- en werkervaring van die historikus self ontstaan en daardeur aan voortdurende korreksie blootgestel is. En dit lei tot 'n tweevoudige resultaat, eerstens dat 'n lewe van historiese ondersoek die enigste grondslag kan wees om met 'n ernstige kennis van sake oor die metode en sy veelerhande vraagstukke te kan praat en tweedens dat die historikus gewoonlik gedurende die grootste gedeelte van sy historiografiese loopbaan verplig word om met metodes te werk wat hy met verloop van tyd meer as een keer sal wysig.

Die slegste benadering vir die rekonstruksie van 'n histories geworde gedagtewêreld waarvan ons nie meer die regstreekse Einfühlung besit nie, en veral nog wanneer daardie gedagtewêreld slegs uiters spaarsaam en baie fragmentaries gedokumenteer kan word, is om die ratio te beskou as 'n vermoë wat ' $n$ volstrek selfstandige bestaan voer en wat in 'n lugleeg ruimte 'n volstrek outonome ontwikkeling beskryf, wat enkel aan Logisiteit sou beantwoord. Dit geld van elke ratio, ook van die filosofiese. Die lewensloop van die wysbegeerte onderstreep feitlik vir elke tydvak die waarheid daarvan, ofskoon daar onbetwisbaar ' $n$ proses van groter verselfstandiging van die wysgerige denke met verloop van tyd in 
die Weste plaasgevind het. Nogtans mag die opkoms en die evolusie van die eksistensialisme in ons eie twintigste eeu as bewys geld dat daardie proses van verselfstandiging nog lank nie so volstrek is as 'n mens hom wel voorstel nie. Teoretiese wysgere kan hulle desnoods die weelde veroorloof om hulle as Rassionalistiese mandaryne aan te stel; historici van die wysbegeerte daarenteen kan dit nie.

Ons sal derhalwe twee opvattings met betrekking tot die geskiedenis van die wysbegeerte moet onderskei: 'n rasionalistiese en 'n historiese. Beide konsepsies weerspieël eenvoudig twee konsepsies van die filosofie in sy geheel en van die funksie wat dit in die globus intellectualis van mens en maatskappy vervul. Die rasionalisitese konsep vertrek van die gedagte van 'n eiestandige, outonome, selfskeppende en selfontwikkelende ratio wat enkel aan sy eie wetgeuing van logiese konsekwensie en sistematiese geslotenheid beantwoord, wat sy funksie in die dialektiese bewerking van aannames en bewysvoerings ontdek en uiteindelik slegs een terrein van ewolusie of geskiedenis erken, nl. die opeenvolgende refleksie oor die logisiteit van soortgelyke bewerkings. Die ratio vervul dan in die denklewe van die mens dieselfde rol as die staat in die oë van die eertydse liberalisme, nl. die rol van polisietoesig, nie oor die vryheid van elkeen nie, maar oor die korrektheid van die denke. Verder as tot hierdie verstandelike polisiefunksie gaan die rol van die filosofie nie.

Die historiese konsep beskou daarenteen die filosofie as 'n wesenlike, positiewe gewrig van die geestesleue, wat op die denkende mens afkom met sy lading problematiek stammende van sy religieuse en lewensopvattings, van sy sedelike normatiek, van sy politieke en sosiale beskouings en toestande, van sy wetenskaplike insigte ens. en wat probeer, soos Trendelenburg dit 'n keer gesê het, om 'n rasionele, denkende herskepping van lewe en werklikheid te wees. Sy spesifieke funksie bestaan daarin om van daardie kompleks - laat ons dit 'n historiese totaalmoment noem - rasioneel rekenskap te gee deur sy verbinding tot 'n homogeen sluitende geheel wat deur sy reduksie tot die laatste archai of beginsels, deur sy sistematiese ordening, deur sy kritiek op inhoud en vorm en deur die bou van ' $n$ normatiewe stelsel van vingerwysings vir logiese en etiese behoorlikheid, verkry word.

In laasgenoemde geval besit die filosofie benewens 'n analities-kritiese funksie ook 'n sosiale funksie. Laasgenoemde 
funksie stel nie ' $n$ profetiese nie, maar 'n refleksiewe wete daar. Nie een filosofie word in die ratio uit die lugleegte gebore nie. Die wysbegeerte gaan nooit aan die lewe as 'n profetiese skou op die toekoms vooraf nie, maar is steeds 'n reaksie van die rasioneel-denkende mens op die lewensvoorwaardes en die werklikheidsgrense waarin sy bestaan verloop. Die gevolge van beide opvattings vir die konsep van die filosofiegeskiedenis lê voor die hand. Die rasionalistiese ontleen aan die dokument (die tekste) die gegewenheid van denkbeelde en bewysvoerings sonder om na hulle herkoms of ontstaan te vra, met die bedoeling om die progressiwiteit in die logiese ewolusie daarvan vas te stel. Die historiese daarenteen vertrek van dieselfde dokumentêre informasie met die bedoeling om te verklaar waarom denkbeelde en bewysvoerings daar is en waarom hulle met mens, ruimte en tyd verander. Die logisiteit daarvan is die tweede gesigspunt maar slegs in sover dit dien om die fisionomie van die wysgeer of van die wysgerige situasie te beskryf. Daarbuite kan enkel sistematiese, nie historiese belang nie heers.

Wanneer die wysgeer die sintetiese eenheidsvisie van 'n historiese situasie konstrueer, is hy nie bloot ratio nie, maar 'n lewende bestanddeel van daardie situasie self wat oordele aanvaar en beoordeel, wat twyfel en kritiseer nie eksklusief in funksie van abstrak-logiese imperatiewe nie, maar in funksie van 'n eenheid wat die gesamentlike denklewe as 't ware tot die eenheid van 'n grond-tema of 'n grond-patroon herlei. Hierdie konsep was steeds op verskillende vlakke die Westerse by uitstek. Selfs Hegel se konstruksie kan nie met die rasionalistiese op een lyn gestel word nie. Slegs die analitiese wysbegeerte van ons tyd, wat die filosofiese tot 'n dialektiek van begrippe en woorde herlei en sy taak tot 'n suiwering van die spraakgebruik beperk, het hierdie tradisionele visie versaak, maar hom daardeur ook die weg na enige geskiedkundige begrype afgegrendel.

Reageer die mens op ' $n$ historiese situasie deur middel van 'n rasionale, tematiese eenheid, tog beteken sulks nie dat daardie eenheid ewig en onveranderlik behoort te wees nie. Inteendeel, dit wissel onophoudend onder die druk van die tydgebonde en tydgegewe situasie self. In die klassieke Griekse tyd was dit die polis, religie en politiek terselfdertyd. In die Middeleeue was dit die naturalisme van die Skolastiek, op sy beurt 'n produk van die geleidelike opstanding van die stad- en 
burgermaatskappy uit die God- en bodemgebonde agrariese Feodaliteit. In die Eeu van sisteme en metodes, die XVIIde, was die eksakte wetenskap die leiding- en rigtingsbepalende kategorie en rigsnoer van die gedagte lewe, en later die emansipasiewil van die mens uit die gebondenhede van Altaar en Troon in die beide liberale eeue wat aan die van ons voorafgaan. En ons, te minste in sy eerste helfte, onredderde eeu is gekenmerk deur 'n gees van ontvlugting: die mens van die twintigste eeu wat van die werklikheid, die lewe en die omringende wêreld wil wegbreek en daarom vlug eerstens in die delectatio morosa oor die onsinnigheid van sy bestaan en andersyds in die versaking aan alle realiteite en probleme wat die Avondland as die wese en die bestaansrede self van sy filosofie beskou het, om in 'n bisantinistiese woorde- en begrippespel op te gaan. Dit by wyse van inleiding.

Meer as watter ander periode ook is die geskiedenis van die Griekse wysbegeerte blootgestel aan die wêreld- en geskiedenisvreemde verhoudings van die rasionalisme onder die verstaanbare voorwendsel dat slegs die tekste met hulle rasionele inhoud vir die filosofie as sulks die geskiedkundige dokumentasie kan vorm, en dat die geskiedenis dan verder bestaan in die logiese ontleding, die sistematiese verbinding, en in die ontuikkeling van die motiewe van denk of wat die tekste aan die hand gedoen het.

Ongetwyfeld is die tekste en hulle inhoud historiese gegewens. Sonder hulle immers sou daar niks wees nie. Die ge. skiedenis egter vang eers aan, wanneer daardie rasionalistiese, filosofiese voorwerk gedoen is. Die geskiedenis behoort ons immers rekenskap te gee, nie enkel in hoever die tekste 'n logiese ontwikkeling van denkbeelde behels of nie, maar eers en veral waarom die tekste daar is en waarom hulle met die gegewe inhoud tot stand gekom het, of, met ander woorde, waarom die mens die motiewe wat ons in die tekste verneem as die motiewe van sy denke in die plek van andere gekies het.

En dit is lank nie 'n paradoks om te beweer dat 'n mens 'n baie goeie insig en kennis van die tekste kan hê sonder om dieselfde tekste in hulle hoedanigheid van historiese gegewens te verstaan nie. Ons kan bv. die Platoniese dialoë in hulle dialektiese opmaak, in hulle materiële inhoud en in die konsekwentheid van hulle voortgang goed onder die knie hê sonder om die mens en die denker Plato ook maar in die geringste mate te ken, sonder om in die mens as die maker van sy ge- 
dagte belang te stel, en sonder om hom in die maalstroom van die eietydse lewe te sien beweeg as 'n lewende wese en nie as 'n rasionalistiese maniak of marionet wat in die ivoortoring van sy Akademie netjiese dialoë slyp nie. En die vraag bly dan nog altyd oop of mens die lewende en historiese betekenis van die dialoog of van sommige altans, kan vat en verstaan, wanneer ons onkundig bly en opsetlik onkundig wil bly van die hele lewenskring wat so 'n dialoog geïnspireer en omraam het, waaraan dit tog sy wesenlike betekenis as histories konstruktiewe dokument ontleen. Ongetwyfeld is dit moontlik om 'n soliede dialektiek met betrekking tot die ontologiese Godsbewys te ontwikkel en dit in sy teoretiese vervlegtheid of in sy sofistieke verborgenhede aan die lig te bring, maar Descartes bly desnieteenstaande 'n volkome vreemde figuur, 'n Deus ignotus, en die bestaansrede van die ontologiese Godsbewys in die raamwerk van Descartes se filosofie - en eers dan is so 'n bewys tog 'n historiese gegewe - is daardeur nie in die geringste mate opgehelder nie.

Wat nou die gevolge van die historiese onkunde betref waarvan die geskiedskrywing van die Griekse wysbegeerte so dikwels die onbewuste slagoffer word, moet ons in die eerste plek as algemene anomalie vooropstel tot watter eensydigheid die staat waarin die materiaal hom bevind in hierdie geskiedskrywing lei, wanneer mens bloot die wat-vraag stel sonder om die historiese konteks daarby te betrek. Ons kennis van die Griekse wysbegeerte is, afgesien van 'n paar gelukkige uitsonderings, enkel fragmentaries, iets waarvoor ons die ge bruik van die papirus as skryfstof en miskien ook wel die eensydige ontwikkeling van die christelike Patristiek verantwoordelik moet hou. Deurlopende tekste in die ware sin van die woord is daar betreklik min; van fragmente daarenteen, dit wil sê, uit verband gerukte anhalings is daar 'n redeliks aantal. Die geskiedenis is deur hierdie staat van sy materiaal verplig om sy rekonstruksie van denkers en gedagtes op 'n uitsonderlik arm en onvolledige doxografie te grondves. Ons moet egter hierby in herinnering roep dat die aard en die omvang van die bewaarde fragmente nie in die eerste plek deur die betrokke denkers en hulle destyds sirkulerende werke self bepaal word nie, maar afhang van die belangesfeer wat die later rapporteurs gelei het by die keuse van hulle anhalings en verwysings. Ten gevolge van die miskenning of veronagsaming van hierdie nogtans elementêre waarheid het die 
Voorsocratici op hierdie manier amper eksklusief ,kosmoloë" geword, nie omdat hulle inderdaad min of meer eksklusief kosmoloë gewees het nie, maar omdat Aristoteles, die vernaamste bron vir die fragmente wat tot ons gekom het, hom enkel vir hierdie soort tekste geïnteresseer het, toe hy, as goeie metodieker, in die eerste boek van die Meta ta Fusika 'n historiese oorsig van die kosmologiese spekulasie in die verlede ten beste wou gee. Nou het die Aristotelesstudie ons sindsdien op oortuigende wyse geleer dat daardie eerste boek, in teenstelling met die eertydse opvatting, nie bedoel was as 'n inleidende boek tot die metafisika of die protè filosofia (of ontologie) nie, maar wel as 'n inleiding tot die fisika. En hierdie bestemming bepaal watter ekserpte uit die Voorsokratiese literatuur vir sy doel belangrik was en watter ander hy sonder skroom en sonder beswaar oor die hoof gesien het. Waaruit ek van my kant tog mag besluit dat die Voorsokratici in ons hand boek kosmoloë geword het, eenvoudig omdat Aristoteles toevallig op 'n bepaalde oomblik in die Voorsokratiese natuur. kennis belang gestel het en die resultate van sy navorsing op hierdie gebied geboekstaaf het, en omdat dit langs hierdie om pad deur dieselfde toeval wat vir andersoortige tekste van dieselfde denkersgroep nie so goedwillig was nie, vir ons bewaar gebly het. En daaruit vloei verder voort dat om sistematiese visies oor die vroegperiode en sy verteenwoordigers te bou, steeds as 'n twyfelagtige spel beskou moet word. Sekerlik getuig die outensiteit van Aristoteles se fragmenteversameling daarvoor dat die kosmologiese spekulasie aan die Voorsocratici nie vreemd was nie, maar dit laat geen historikus toe om te beweer dat hulle aandag in 'n eksklusiewe of ten minste in 'n opvallende mate daarop gekonsentreer was nie.

En daarmee verval die kernstuk van die periodisering wat die historiografie in die ewolusie van die Griekse filosofie ingevoer het en wat per slot van sake vir ons veel meer 'n hinderpaal daarstel, waardeur die intelligensie van die Griekse denke as historiese proses bemoeilik word. In hierdie omstandighede kan selfs die beste intelligensie van die fragmente nie by magte wees om ons dienaangaande iets te leer en sekerlik nie by magte wees om die eksklusiewe aard en waarde daarvan te bepaal nie. Die hermeneutiek van die Voorsokratiese denke hang derhalwe slegs gedeeltelik van die hermeneutiek van die tekste af en moet in ' $n$ ewe groot mate aangevul word deur die rekonstruktiewe doxografie wat ons met die persone, die 
milieu en die historiese raamwerk vertroud maak, wat die regstreekse causae secundae van die betrokke fragmente was. En ek wil hier nog nie eens gewag maak van die feit dat ons met fragmente te doen het wie se saaklike verband ons prakties altyd ontgaan nie, waarby die gevaar dreig om persoonlike sistematiese vooroordele met objektiewe hermeneutiek te verwar. Wat daar ook al mag van wees, dit bly slegs 'n anomalie en niks meer nie om die Voorsokratiese denke as ' $n$ tydvak van eksklusiewe kosmologiese bespieëling voor te stel en om die aanwesigheid van sommige ander gesogte fragmente as dié wat die Aristoteliese groep aan die hand doen, nie in die beskrywing van die gedagtelewe te laat meetel nie, omdat hulle miskien minder in die vooropgestelde kaders pas.

In vroeër tye het die opkomende klassieke filosofie ons die Grieke voorgespieël as ' $n$ volk van ideale paradysmense toegerus met al die gawes en deugde van 'n ideale mensdom, en dit het ongeveer honderd jaar gelede Jakob Burckhardt heel wat sorge gebaar om weer 'n min of meer realistiese kyk op die Griekse mens en die Griekse lewe ingang te laat vind en om die Griek van die hemel weer na die aarde terug te bring. Die naïwiteite van Winckelmann is, helaas, selfs in ons tyd nog nie heeltemal oorwen nie. Sindsdien het 'n tweede, nie minder naïewe, opvatting van die Griekse denke en denkers sy intree gedoen, nl. die rasionalistiese, waarvolgens die Griekse lewe ons 'n volkome voorbeeld van oorgawe aan die ratio lewer, wat bloot rasionele konsekwensie in die oog gehad en nagestreef het. Mens behoort nie 'n groot klerk in Griekse geskiedenis te wees nie om met volstrekte sekerheid te kan sê dat die Griekse „werklikheid" heeltemal anders was as hierdie verwronge, uit Angelsaksiese insularisme gebore Griekebeeld. 'n Tweede anomalie het uit daardie rasionalistiese naïwiteit ontstaan, wat m.i. die gesonde opvatting van die Voorsokratiese denke verhinder.

Die fragmentariese oorlewering of doxografie van die Griekse vroegtyd in globo uit twee helftes: aan die een kant uit fragmente wat 'n aantal observasies van astronomiese, meteorologiese en fisiese aard vaslê en uit 'n aantal ander wat spekulasies oor die ,een" bevat, waartoe die makro- en die mikrokosmos as tot sy laaste beginsel herleibaar is en herlei word. Nou heg die historiografie van die Griekse denke nie slegs die oorweënde belang aan laasgenoemde spekulasie nie - iets wat ons nog enigermate van wysgere sou kan verwag 
- maar gaan dikwels agteloos en met bekwame spoed aan die fisiese observasies verby. En nie altyd sonder om blyke te gee van die gebrek aan waardering waarmee die rasionalistiese geskiedskrywing hulle bejeën nie. Ek moet daar onmiddellik stelling teen neem en in die lig stel hoe grondig verkeerd hierdie perspektief op die Griekse denke is en hoe enkel en alleen die rasionalistiese vooroordeel daarvoor verantwoordelik gehou moet word. Want waarskynlik was die werklike stand van sake glad die teenoorgestelde. Die fisiese wêreld in sy samestelling en sy verskynsels was in daardie vroegtyd die belangrikste deel van die filosofiese arbeid, omdat die Voorsokratiese lewensmilieu die koloniale wêreld tot 'n maritieme bestaan gedwing en gevoer het. Amper al die betrokke observasies handel oor praktiese probleme van astronomie, aardrykskunde, meteorologie, meetprosesse, ens., dinge wat almal regstreeks of onregstreeks met oriëntering en verkeer te land en ter see saamhang. Die Voorsokratiese problematiek het nie ontstaan uit die feit dat die Grieke as rasionalistiese wêreldwondere met behulp van 'n dialektiese oervermoë onmiddellik na die metafisies-laaste gegryp het nie, maar wel uit die feit dat die ratio met al sy skerpsinnigheid en die verbeelding met al sy uydsheid geroep was om die kollektiewe lewe op sy taak voor te berei en vir sy taak uit te rus. Dat die Grieke van die staanspoor gevra het wat agter die verskynsels en die positiewe navorsing van hulle praktiese natuurprobleme lê, mag geld as 'n teken vir die onbetwisbaar rasionaliseerde kenmerk van die Griekse gees, maar kon m.i. nie as bewys ingeroep word om die sg. metafisiese bespieëling as 'n rasionalistiese creatio ex nihilo te beskou nie. Die metafisika is gebore uit iets wat ons globaal fisika kan noem, en die fisika self is gebore uit die praktiese probleme wat die lewe van opkomende handelstede stel van sy verantwoordelike beheerders. En dit is ' $n$ bekende feit dat meer as een Voorsokratiese wysgeer in een of ander hoedanigheid by die polis-administrasie betrokke was.

Met ander woorde die historiese fout wat in die eksklusiewe beklemtoning van die metafisiese bokant die fisiese geleë is, is nie ' $n$ fout wat ons aan die doxografie moet toeskryf nie, maar dit is inteendeel 'n misvatting van die filosofiese historiografie wat die mens uit sy natuurlike milieu isoleer asof die lewensvreemdheid 'n uitsonderlike waardigheid aan die wysgeer sou verleen, wat hom willekeurig wil inpers in 'n ryk van suiwer rasionaliteit en wat een of ander karikaturale 
professorebeeld uit die filosofiese wêreld van die moderne tyd op 'n hele volk en dan nog op 'n volk uit 'n primitiewe tydperk wil afdruk. Gaandeweg wanneer aan die praktiese lewensbehoeftes voldoen was, het die aandeel van die ratio ruimer geword, maar ewemin as die wetenskap is die Griekse filosofie gebore nòg uit die gees van die mistiek soos Joël nog gedink het nòg uit die gees van enige tegnies-logiese ratio nie. Die oorbeklemtoning van die spekulatiewe, metafisiese gerigte oorlewering lei m.i. tot 'n baie artifisiële opvatting en waardering van die Griekse denke, wat nie uit die historiese gegewe self nie, maar enkel en alleen uit 'n sistematiese vooroordeel voortvloei.

Uit dieselfde gees is ' $n$ derde anomalie gebore waarteen nie genoeg gewaarsku kan word nie, nl. die projeksie of die verskuiwing van die Hellenistiese Griekebeeld na die klassieke. Tussen beide het hom nogtans 'n ontsaglike verskynsel voorgedoen wat alle menslike houdings en verhoudings volkome gewysig het, $\mathrm{nl}$. die ondergang van die polis as geestelike lewensmaatstaf en as laaste meta-individuele dwangorde vir die mens. Die polis was 'n skepping uit die emigrasietyd en is deur die behoeftes van die emigrasie verklaarbaar. Die klassieke filosofie is amper in sy geheel die werk van die aristokrasie, al mag in later tye die groep of party meer op gesindheid as op sosiale stande-afstamming berus. Daaruit kan ons die funksie wat die filosofie in die klassieke tydvak vervul aflei, veral waar ons hierby in gedagte hou hoe ekstensief die term filosofie deur die Grieke opgevat word. Die filosofie is nie 'n bloot abstrakte spekulasie nie, maar 'n paideia, dit wil sê, 'n opvoedingstelsel wat 'n bepaalde opvoedingsprogram aan die nuwe polisburger voorhou en wat die kwekelingwysgeer wil gereed maak vir die oomblik as hy die staatsleiding opnuut in die hande sal neem.

Op hulle beurt versorg die Sofiste en die retoreskole die adekwate opleiding van die jong mense vir hulle boulè-pligte. 'n Mens kan die Pytagoriese Bond tog nie anders verstaan dan as ' $n$ religieus-aristokratiese gemeenskap of as 'n opvoedingsinstituut vir 'n opposisie wat hom voorberei om by die eerste geleentheid die verlore leisels weer op te neem nie. Die geskiedenis leer ons dat die Bond inderdaad na die mag gegryp het en dat die Pytagoreërs daardie mislukte magsvertoon met 'n bloedige repressie moes betaal, wat hulle tot 'n lang ondergrondse bestaan en tot 'n wetenskaplike (wiskun- 
dige) spekulasie sonder religieus-politieke bygedagtes gedoem het. Plato se Akademie vertoon 'n gelyksoortige karakter, maar daar kom ons straks op terug. Die mispryse waarmee Plato die Sofiste bejeën, omdat hulle as besoldigde professore optree, mag as 'n aanduiding a contrario geld dat sy eie Akademie niks anders as 'n onbaatsugtige diens aan die burgerlike gemeenskap in die oog gehad het nie, en in sy diepste wese eweneens aan konkrete, politieke oogmerke skatpligtig was. Ook die pansofia van Aristoteles se Lyceum wys reeds daarop dat die dae van die polis getel is en dat sy opvatting volgens die ou filosofie se doelwit van 'n aristokratiese reconquista die doelwit van die Akademie - nie meer met die nuwe, politieke verhoudings van die tyd tred hou nie. Maar dit wys ook daarop dat die panhellenistiese Commonwealth onder Macedoniese supervisie 'n baie universeler opleiding vir die nuwe burger vereis, en dat die paideia te dien effekte ook nuwe leermetodes behoort te vind en te hanteer. Die panhellenistiese burger is nie ' $n$ politikus in dieselfde sin as die polisburger nie. Hy sal in die beste geval 'n gewestelike administrateur in 'n groter politieke verband wees en die verbreding van die gesigsveld in elkeen van die polis wat deel van 'n wêreldimperium uitmaak, weerspieël hom in die gees waarop die Lyceum berus. Maar altyd beantwoord die filosoweskool in sy verskyning en optrede aan die paswoord dat die nuwe "burger" afhanklik is van 'n nuwe "mens" en derhalwe van 'n nuwe paideia. Athene, die ewig opstandige, het die rigting van Aristoteles se skool verstaan maar op bewuste wyse gewantrou. Onder die leerlinge van die Lyceum tel ons (sover my bekend) nie een Athener nie. Dit was altans in die praktyk 'n regstreekse skepping ten geriewe van die panhellenistiese oikomenè in wording.

En Aristoteles het daarmee as sluitstuk van die klassieke tydvak die brug na die toekoms geslaan. In die Diadoche-tyd het Athene onverminderd 'n aktiewe kristallisasiepunt vir die Griekse filosofie gebly (al moet dit later daardie rol met ander stede, soos bv. Aleksandrië deel), maar sy outonome skeppende vermoë behoort tot die verlede. Een van die merkwaardigste kenmerke van die Hellenistiese tyd bestaan daarin dat die wysbegeerte wel 'n Griekse na die medium, maar 'n Semitiese na die persone en straks ook na die inhoud word. Die Stoïsisme is 'n Semitiese skool met die drie groot leiers uit sy eerste tyd: Zeno, Kleanthes en Chrysippos, van wie 
nie een 'n outentieke Griek is nie. Die enigste outentieke, Ioniese gedagtestroming is die Epikuristiese, en hierdie IoniesAtheense moralisme sal sy karakter van aristokratiese mensekultuur tot diep in die Romeinse tyd voort bewaar, waar ons dit as die geestelike lewenskode en die lewensprogram van die republikeinse aristokrate aantref. Die individualisme wat die Hellenistiese tyd kenmerk, is die resultaat van die polisondergang, en die innige verbinding tussen die herwaardering van die enkeling en die ondergang van die politieke gemeenskapstruktuur word geïllustreer deur die algemene erkenning van die kosmopolitisme as mensebindende, of ten minste as geleerdes-bindende entiteit. Die polis self word opgevolg deur gekonsolideerde wêreldryke. Die metafisiese spekulasie verdwyn grotendeels in die enorme kommentarieerarbeid van die volgende eeue en sulks tot by die opkoms van die laat Neoplatonisme. Dit word vervang deur positiewe en eksakte wetenskap aan die een kant en deur 'n ensiklopediese, onderhoudende liefhebbery-literatuur aan die ander kant, wat ons na 'n arbeidledige en politiekledige burgery veruys. Ten slotte ontwaak in die laat Hellenistiese tyd 'n ontsaglike religieus-mistieke literatuur wat uit die geestelike klimaat van die Semitiese wêreld van Voor-Asië stam en wat later nog onder Neoplatoniese beskerming die grondslag sal vorm vir die late, te laat gekome maar nietemin eerste teologieë van die heidendom. Maar met die rasionalistiese, diesseitige en volstrek rasioneel-spekulatiewe wese van die klassieke tydperk staan die Hellenistiese in 'n skril kontras. Die verklaring daarvoor moet ons in die ontwrigting van die sosio-politieke en religieuse dwangorde soek wat die ondergang van die polis in die Griekse gees veroorsaak het en in die Uberfremdung van daardie gees deur die Semitiese ideologieë waarvoor Alexander die Grote die moontlikhede geskep het. Maar beskou uit ' $\mathrm{n}$ outonome, bloot rasioneel-dialektiese gesigshoek is hierdie ontwikkeling onverstaanbaar en onverklaarbaar.

Die rasionalisties-outonome konsepsie van die Griekse wysgerige denke lyk nog 'n ander verantwoordelikheid te moet aanvaar, nl. die misvatting waarvan die vyf geestesgrotes uit die klassieke tydperk die voorwerp is: Herakleitos, Pythagoras, Sokrates, Plato en Aristoteles. Die aard van die misvatting is egter nie 'n eenvormige vir almal nie. Een van die onbegryplikste anomalieë van 'n lewensvreemde historiografie van die wysbegeerte en van die miskenning van sy sosiale 
rol en funksie in die Griekse wêreld is die onderwaardering waarvan Herakleitos so lank en by so baie historici die slagoffer is. Die wêreldbeskouing van die laaste erfgenaam uit die koningsgeslag van Efesos is die enigste filosofie voor Plato wat getuig van 'n waaragtige aristokratiese grandezza. Dis werklik jammer dat hy vir ons slegs fragmentaries bewaar gebly het, want ek twyfel daar nie een oomblik aan dat sy werk in die teengestelde geval vir die van Plato nie sou moet onderdoen nie. Nietzsche was een van die veiniges wat hierdie grandezza intuïtief en spontaan en baie beter as die vol-geskoolde filoloog Wilamowitz aangevoel en verstaan het. Ons mag hierby herinner aan die feit dat die Grieke self onder die indruk van daardie grootsheid gekom het. So het Herakleitos in ' $n$ baie sterker mate as enige ander rigting die kosmologiese en wetenskaplike spekulasie van die Stoa bepaal, en langs hierdie kanaal het sy wêreld- en lewensvisie in die vleis en bloed van die Griekse denke oorgegaan. Ook hy het hom oor die „een” soos alle Grieke besin, maar wanneer ons die fragmente hulle natuurlike taal laat spreek en nie by voorbaat deur die kosmologiese of rasionalistiese vooroordeel vervals nie, moet ons tot die slotsom kom dat sy werk nie 'n waaragtige Peri Fuseos nie, maar 'n egte politieke traktaat was en as sodanig gewaardeer behoort te word, onverskillig of dit in aforismestyl of in deurlopende teks geskryf geword het. Ons moet onthou dat die betiteling Peri Fuseos waaronder die meeste Voorsokratiese werke bekend staan, iets wat nie weinig bygedra het tot die kosmologisering van die Griekse vroegtyd, nie van die betrokke filosowe stam nie, maar van die biblioteekbeleid van Alexandrië se Mousaion.

Ongetwyfeld bied sy eenheidsbeginsel „vuur" niks verbasends en behoort nie as 'n uitsonderlike verskynsel in die archèspekulasie van die Voorsocratici gewaardeer te word nie. Die Grieke het hulle blykbaar nooit 'n geestelike beginsel as eerste oorsaak kon voorstel sonder om dit in 'n materiële dubbelganger in te klee nie. Maar Herakleitos was die eerste profetiese getuie wat die universele kousaliteit in die gees of die logos geplaas het en daarmee die ontsaglike denkmiddel ontdek wat die Griekse denke nie meer sal loslaat nie en wat ook, nadat dit in die aanhef van die Johannesevangelie solenneel ingeroep geword het, die christelike teologie en veral die christelike apologetiek gaan verlei tot 'n koene gelykstelling van die Heraklitiese logos met die evangeliese Christus- 
figuur. Die eerste teken kan ons in Justinus Martyr se pleidooi opspoor. Die nous-gedagte van Anaxagoras en Aristoteles is per slot van sake maar 'n naamverandering daarvoor. Hierdie logos-spekulasie wat in dieselfde hoogste regio van die absolute beweeg as Plotinos se „Een”, gaan terselfdertyd gepaard met die „realistiese" konsep van die wêreldgebeure as 'n universele wordingsproses (die panta rei-begrip), en die dualisme tussen die logos-absoluutheid as onwrikbare beginselvastigheid van die gees en die universele relativisme van alle realiteitsgebeure in die ondermaanse bly tot vandag toe die groot geheimnis van elke metafisika wat nog vatbaar is vir die wesenlike problematiek wat die laaste dinge raak en waarmee die grootheid van die Weste staan of val. Maar om Herakleitos met die maatstaf van die rasionalistiese dialektiek te benader is ' $n$ onbegonne taak en dit mag miskien die verborge rede wees waarom ons die uitmuntende plek van daardie duister Hoëpriester van die Dianatempel so selde in sy volle sin en waarde aantref.

Dieselfde rasionalistiese geskiedskrywing gee blyke van 'n volslae gebrek aan historiese sin waar dit die posisie van Pythagoras en sy Orfiese Bond begriploos en gedagteloos met die bemerking afdoen dat die Pythagorisme die getal as eenheidsbeginsel van die stof vooropgestel het nadat Milete en die ander Ioniese emigrantestede daarvoor water en vuur ingeroep het. Met die gedagte dat hy die kosmologiese metafisika in 'n getallemistiek omgeskep het is sy historiese posisie nog lank nie omskryf nie. Sonder om in te gaan op die groot waarskynlikheid dat daardie getallebespieëling nie tot die oorspronklike geestesgoed en die primitiewe gedagtewêreld van Pythagoras en sy skool behoort het nie, maar wel tot dié van die Bond in die diaspora na die drama van Metapontos en ander Suid-Italiese stigtings, behoort ons vir die Bond as geheel en van die staanspoor as 'n uitgesproke aristokratiese emigrasieklub te behou wat hom in sy nuwe tuiste deur 'n selfdissipline van gees en lewe die reconquista van die emigrasiepoleis van die Magna Graecia ten doel stel. Die Ioniese wysbegeerte en wetenskap moet beskou word as manifestasies van die koloniale bestaan van die polis en van die administratiewe sorge van die eerste denkers. Die Pythagoriese daarenteen is met die meeste beslistheid uit die gees en die nood van 'n politieke opstandigheid en uit die vaste wil tot 'n aristokratiese restourasie gebore. Sy kensketsende 
eienaardigheid - 'n mens voel huiwerig om dit te sê - is die ongriekse karakter van die religieus-etiese mensepaideia waaraan die lede van die Bond onderwerp word en wat ongetwyfeld vreemd was aan die tegniese wetenskaplikheid van die Ioniese tuislande. Alles wat ons van die Pythagorisme te weet gekom het, verbied ons om die Bond te beskou as 'n assosiasie van suiwer gedesinteresseerde geleerdes of geleerdheidsoekers wie se aktiwiteit op kosmologiese bespieëling toegespits was. As daar een groep denkers in die Voorsokratiese Oudheid is wat met alle duidelikheid in hulle denke, organisasie en lotgevalle op ' $n$ antropologies-politieke afswenking van die filosofie wys, dan is dit ongetwyfeld die Pythagoriese groep. Die Pythagoras as die bemiddelende persoon opgetree het om die Orphiese klubs in die breë stroom van die filosofie in te burger, is vir my niks verwonderliks nie, want die Orphisme stel op sy beurt 'n geestelike paideia vir aristokratiese konsumpsie daar. En Plato se ontvanklikheid vir dieselfde Pythagoriese Orphisme sal wel sy oorsprong vind in die aristokratiese solidariteit van hulle persone en hulle geestelike strewe.

Ook die Sokratiese „probleem" het per slot van sake sy laaste grond in 'n gelyksoortige misvatting van die sosiale funksie wat die filosofie in die Griekse lewe vervul, en met die suiwer rasionalistiese vooroordeel as leidraad kan dit nie 'n voldoende genuanseerde oplossing kry nie. Die Sokratiese probleem bestaan uit twee lede: eerstens, wat is die histories waaragtige Sokratesfiguur: die Xenofontiese of die Platoniese? En tweedens hoe behoort ons Sokrates te waardeer: as 'n rebel of as 'n suiwer martelaar van die vrye rasionalistiese denke? M.i. kan daar geen twyfel bestaan dat die Platoniese Sokrates ' $n$ kreasie van Plato en nie 'n blote weergawe, selfs nie 'n gestiliseerde weergawe van 'n historiese Sokrates is nie. Die Sokrates van die dialoë is eenvoudig die woordvoerder van Plato se gedagtewêreld wat as teenvoeter van die demokratiese Sofistiek en as antidemokratiese partyleier van die Sokratesdrama 'n weergaloos suksesvol agitasiemoment gemaak het. Sokrates het die slagoffer geword van 'n regering wat uit die emigrasie teruggekeer het en wat soos die terugkerende emigranteregeringe van alle tye in die blinde repressie 'n alibi vir hulle eie lafheid soek. Die weergalose literêre talent van Plato het daarin geslaag om van 'n waarskynlik ongevaarlike, loslippige burgerkind 'n geestesheld te maak, 
en die Xenofontiese Sokrates is met die hoogste waarskynlikheid ' $n$ baie betroubaarder historiese Sokratesbeeld as die vergoddelikte een wat die Platoniese dialogeertalent geskep het. Aan die ander kant is daar die tweede probleem, nl. hoe om die geval Sokrates van etiese standpunt te beoordeel. In die loop van die eeue het daardie oordeel voortdurend van vergoddeliking tot veroordeling gewissel, nie omdat die geskiedkundige facta die verskillende generasies daartoe genoop het nie, maar omdat die persoonlike geestesgesteldheid van die opeenvolgende tydvakke hulself in sy houding en noodlot weerspieël gevind het. Tye en persone wat die algemene welsyn en die oppergesag van die gemeenskap aanvaar, beskou hom as 'n rebel; tye en persone wat die algemene welsyn en die gesag van die gemeenskap aan die hoër magte van die persoonlike gewete ondergeskik maak, moet hom as 'n martelaar beskou. Nie een van beide houdings is egter objektief toereikend om Sokrates te beoordeel nie, want beide weerspieël veelmeer die persoonlike gesindheid van die beoordelende party as die gesindheid van die beoordeelde man self.

Alles wel oorwoë behoort ons vir die historiese Sokrates - of dit nou die Xenofontiese of die Platoniese is - die hoogste agting te koester. Hy het nie gebruik gemaak van die geleentheid om aan die eksekusie te ontsnap nie. Maar dit is tog nie voldoende om hom van elke skuld vry te spreek nie. In die veronderstelling dat Plato die geestelike rol wat Sokrates gespeel het betreklik korrek sou weergegee het, kan ons nie anders nie as om toe te gee dat Sokrates die geestelike waardes en tradisies waarop die Atheense polis berus en wat vir elke Griek 'n absolute dwangorde verteenwoordig, deur sy dialektiek ondermyn het en dat hy dientengevolge die klagstaat van jeugbederwing met die repressiewe gevolge wat claarmee verbind is heeltemal nie as 'n onbillike een kon beskou het nie. Die enigste wat ekself hierby moet aanstip, is die feit dat die eietydse Sofiste ongemoeid en ongesteurd baie erger dinge vir die sedelike fundament van die Atheense demokrasie kon verkondig en dat derhalwe die sanksie wat Sokrates tref heeltemal buitekant die heersende verhoudings staan en dat daar dus teen die persoon van Sokrates gediskrimineer geword het om redes wat ons nie bekend is nie. Maar ten opsigte van die klagstaat self moet Sokrates onbetwisbaar as rebel beskou word, en wanneer daar beweer word dat die opstandigheid ingegee was deur hoër belange, moet ek ripos- 
teer dat dit nie opgaan om standpunte en houdings wat in ons liberale tyd algemeen aanvaar word om te projekteer op situasies wat so ver van die van ons verwyder is as die Atheense ten tye van Sokrates. Die suiwer rasionalistiese historiografie wat op die individualistiese standpunt staan, maak van Sokrates en moet van Sokrates 'n martelaar maak; die historikus moet daarenteen baie omsigtiger te werk gaan, veral omdat ons te doen het met iemand wie se historiese profiel lank nie evident is nie. Want ons moet in gedagte hou dat sowel Xenophon as Plato vereerders van Sokrates was, en dat ons derhalwe die Xenofontiese Sokrates nie somaar kan afwys op grond van enige politieke meningsverskil of bevooroordeeldheid nie. Ek het hierdie Sokratestema en al die ander wat ek hier bespreek breedvoerig en sonder om my veel aan die koeranteopvatting te steur voorgedra in my gepolikopieerde kursus in die Universiteit van Suid-Afrika. Ek is bly om te kan sê dat amper alles wat ek daarin tien jaar gelede neergeskryf het tans in die laaste skets van die Griekse klassieke beskawing wat die lig gesien het, van die algemene klassieke-filologiese standpunt uit bevestig word, nl. in die jongste boek van Francois Chamoux: La Civilisation grecque á l'époque archaïque et classique (Parys, 1963).

Die Sokratesbeeld wat ons deurgaans voorgehou word is afkomstig van Plato, maar die geskiedskrywing van die Griekse wysbegeerte laat aan die figuur van Plato as lewende, historiese persoonlikheid ewemin as aan dié van Sokrates reg wedervaar. Fundamenteel is in hierdie opsig die twee volgende feite. Eerstens dat Plato een van die leiers van die aristokratiese Spartaparty te Athene was wat die politieke struktuur van Sparta as programmatiese ideaal vir 'n aristokratiese restourasie te Athene as sy persoonlike lewensdoel in gedagte het, en tweedens dat 'n filosoweskool te Athene steeds die opleidingsentrum van 'n politieke groepering is op grond van die beginsel dat die nuwe staatsorde van 'n nuwe paideia vir sy burgers afhanklik is. Dat ons nie elke woord wat Plato uitgespreek of geskryf het aan so 'n politieke oogmerk moet toeskryf nie is duidelik. Maar dat die algemene opset van die skool deur daardie politieke oogmerke geïnspireer word is ewe duidelik. Die rasionalisme van die Griekse gees openbaar hom presies in die feit dat hy geen politieke vernuwing sonder 'n geestelike vernuwing kan sien nie, en dat die verstandelike omskoling - van die merkantiele na die suiwer gees- 
telike - die volstrekte voorvereiste tot so 'n politieke omskoling daarstel. Die inhoud van die geestelike omskoling is nie en kan ook nie in al sy onderdele en detail regstreeks van die politieke oogmerk van die skoolstruktuur afgelei word nic. In sover behou die rasionalisme in ' $n$ bepaalde mate sy regte. Maar as geheel is die Akademie 'n skool van politieke opleiding. En dientengevolge verstaan ons dat Plato die leerlinge wat die skool na voltooiing van die curriculum studiorum verlaat om na hulle respektiewe tuislande terug te keer op die hart gedruk het om hulle daar by die leiding van die stadspolitiek te nutte te maak. 'n Feit wat o.a. nie sonder invloed op die lotgevalle van Aristoteles sal wees nie.

Nie alle dialoë en sekerlik nie alle begrippe en probleemanalitiese gedagtegange van Plato behoort dus regstreeks politieke oogmerke na te streef om met bogaande opvatting verenigbaar te wees nie. Daar kan nie gesê uord dat alle Sokratiese dialoë politieke traktate in dié sin is dat hulle 'n politieke tematiek behandel of daarmee verband hou nie. Nietemin word daar die Sokrateslegende geskep, en hierdie skepping is op sigself beskou 'n onderneming wat uit politieke oorwegings gebore is en politieke oogmerke dien. Maar ek wil veral na een dialoog verwys - een van die vernaamstes - om my sienswyse te staaf, nl. die Staat of die Republiek. Die titel self stel in die vooruitsig dat ons hier met 'n uitgesproke politieke traktaat te doen gaan kry. Maar presies hier staan ons voor die anomalie dat 'n merklike deel - miskien die bekendste deel - nie gewy is aan politieke meditasies nie, maar inteendeel bestem is om 'n summariese uiteensetting van Plato se teoretiese filosofie te gee. Plaas ons dit nou in die lig van ons hoèr aangegewe opvattings, dan kan ons dit nie eenvoudig as 'n konstruksiefout beskou nie, maar wel as 'n opsetlik gewilde en in sy opset ook verstaanbare en gewettigde manier van doen. Plato neem slegs die politiek-pedagogiese taktiek van die Pythagoreiese Bond oor. Die filosofie is die paideia vir die nuwe aristokrasie wat beoog en wat deur Plato opgelei word om eendag die mag in die polis uit die hande van die ploctokratiese demokrasie oor te neem. Plato self behoort tot een van die ou eupatridegeslagte van Athene. Ofskoon trou aan Athene, stel Sparta vir hom soos vir baie Atheners van sy tyd die voorbeeld van 'n politieke stabiliteit daar wat Athene sedert die heengaan van Perikles nie meer ken nie. Hierdie pro-Spartaanse gesindheid het hom in die stad amper 
tot 'n georganiseerde party verenig, waarvan Plato een van die vooraanstaande geestelike leiers was en waarvan die Akademie die geestelike opvoedingsentrum daarstel.

Wanneer die historiograaf hierdie agtergrond in die oog hou, kry hy van Plato se denke en werke 'n baie lewendiger en ook histories waaragtiger begrip as wanneer hy Plato se loopbaan sou wil vul met die logies-rasionele inhoud van sy dialoë .En meteen besit ons die sleutel wat ons die toegang tot die Republiek verleen. Die politieke gedagte wat Plato ontuikkel, geld deurgaans in die literatuur as grootse utopie, as 'n ietwat gek wensbeeld van 'n werklikheidsureemde filosoof wat nie die geringste $\sin$ vir die politieke werklikheid openbaar nie. En hierdie utopiese karakter bewys in die oë van die politieke teoretici hoe gevaarlik dit sou wees om die leiding van die polis - van enige polis, antieke en moderne in die hande van mense te lê, wat die politieke denkbeelde en die filosofiese intermezzo van die Republiek as hulle evangelie aanvaar. Ek moet hierdie misprysende waarderingsoordeel ten sterkste weerspreek. Die politieke leer van die Republiek is nie 'n wêreldvreemde utopie nie maar doodeenvoudig Spartaanse werklikheid, en die Republiek as geheel is niks anders nie as die filosofies onderboude maar essensieel politieke manifes van die Spartaanse party in die Atheense wêreld en in die egte sin van die woord die "evangelie" op wie se fundament die Akademie berus, die fundament, waarvoor die Akademie die beste leer- en werkkragte oplei.

Om hierdie manifes ingang te laat vind moes die bekende Sokrateskonsep of -legende in die lewe geroep word in die periode van die sg. Sokratiese dialoë (waartoe nog die eerste boek van die Republiek self gereken moet word). Na sy eksekusie het Sokrates heel wat simpatie by sy medeburgers geoes en die politieke regime wat hom ter dood gebring het moes baie blaam verduur, in so ' $n$ mate selfs dat Polykrates, 'n Sofis, verplig was om 'n verdedigingskrif op te stel ten einde die handelwyse van die boule goed te praat. Daardie stroom van simpatie het Plato tot eie voordeel uitgebuit en hy het onder die naam en die vlag van Sokrates 'n geesteswêreld geskep wat hoogs waarskynlik uit 'n historiese standpunt beskou as die persoonlike eiendom van Plato, maar wat Sokrates betref, as legendaries beskou moet word, al mag dit in die oë van Plato ' $n$ brandende aktualiteit geniet het. Terwyl Xenofoon, wat as verbanne generaal reeds geruime 
tyd verblyfsvergunning op Spartaanse grondgebied verkry het, in sy afsondering nie dieselfde geleentheid en ook nie dieselfde oogmerke van prakties politieke aard gehad het as Plato nie, en dientengevolge 'n beeld van Sokrates ontwerp waaruit meer historiese waaragtigheid as uit die Platoniese straal. Dit mag miskien nie die mening van Burnet wees nie, wat 'n naïewe vertroue stel in die waaragtigheid van Plato as getuie. Die rede vir so 'n vertroue kan maar in die wêreld- en lewensvreemdheid van die rasionalistiese visie lê wat geen orgaan het vir die sosio-politieke funksie van die filosofie in die Griekse gemenebes nie.

Ook die posisie van Aristoteles, die dwarsdeur raaiselagtige posisie van Aristoteles in die ontwikkeling van die Griekse denke is, onverklaarbaar - en onverstaanbaar, wanneer mens ook hier die politieke dryfveer wat hy in die verskillende fases van sy loopbaan openbaar oor die hoof sien. Ek het probeer om die circumstansiële getuienis (want daar is nie ' $n$ direkte nie) daarvoor by mekaar te bring in my intreerede aan die Universiteit van Suid-Afrika en in die publikasie daarvan onder die titel: Aristoteles en die Macedoniese Politiek (Pretoria, 1957). Ek moet dit alles nie weer herhaal nie. In meer of minder mate bly raaiselagtig waarom Aristoteles die Akademiese skoolkring die rug toegekeer het, waarom hy hom na Assos begewe, waarom hy as hofleraar na Pella geroep word, waarom die Macedoniese skatkis die oprigting van 'n filosoweskool te Athene rojaal finansier, waarom die Atheense publiek die Lyceum boedeer, teruyl die oikomenè dit bevolk, waarom die Lyceum deur Athene hartgrondig gewantrou word en by Aleksander se afsterwe Aristoteles die wyk na Chalkis moet neem om Athene te belet 'n tweede Sokrates-drama op tou te sit. Niks is egter raaiselagtig nie, wanneer ons van die hipotese, en 'n hipotese cum fundamento in re, vertrek dat Aristoteles deur sy persoonlike en deur sy familieverbindings met die politieke personeel van Pella in die diens van dic Macedoniese Panhellenisme staan, maar alles is en bly 'n raaisel, wanneer ons na die model van die rasionalistiese filosofie-opvatting daardie loopbaan tot die verwerping van die ekstreme realisme van Plato en sy ideëleer wil beperk.

Die skoolstigting van Aristoteles besit nie 'n rewolusionêre karakter wat van die gegewe Griekse skoolpatroon afwyk nie. Net soos die Akademie is dit 'n skool van burgerlike opvoeding en net soos die Platoniese is die Peripatetiese filosofie 
'n paideia of 'n leerprogram vir daardie soort opvoeding. Maar 'n verskuiwing het plaasgevind ten opsigte van die oogmerke wat die Lyceum aan die basis van sy opvoeding lê. Aristoteles wil nie soos sy leermeester 'n polis-burger opvoed met die beperkte en bekrompe horison wat die Platoniese nog kenmerk nie, maar wel die oikomenè-burger wat beoog om die Panhellenisme van die Macedoniese politiek tot 'n geestelike en 'n politieke wêreldimperium te verhef. Die universaliteit van die leerprogram weerspieël die universaliteit van die oogmerke en weerspieël ook die praktiese behoeftes, waarin by die verwesenliking van daardie oogmerke voorsien sal moet word. Ook die empiristiese nugterheid van die Noorderling van Stageira (sonderling, al die Noordelinge hel na dieselfde empiriese saaklikheid oor: Demokritos, Protagoras, Aristoteles), dui meer op realpolitieke neigings as op idealistiese hoogdrawendheid soos die Pythagoriese of Platoniese polisaristokrasie. Die Stoïsisme sal die universalisme van Aristoteles se filosofie onder sy vleuels neem. Ten andere, die Stoa word so dikwels misverstaan, omdat dit ook met die gewone rasionalistiese blik aanskou word wat wellig konstateer wat die Stoisisme is en wat die Stoisisme as inhoud behels, maar wat nooit besef en homself selde afvra waar dit alles vandaan kom en waarom dit daar is nie. Indien mens in gedagte wil hou dat die primitiewe Stoa in sy geheel die werk van gehelleniseerde Semiete is, wat hulle weens die Ioniese ubris wat die wêreld tussen Grieke en barbare verdeel, as emigrante wel getolereer maar nooit geaksepteer voel deur die outochtone Griekedom nie, dan verstaan ons waarom die Stoa soos later Jode en Christene (wat voor dieselfde sosiale vraagstuk te staan kom) as metafisiese onderbou vir hulle praktiese emigrante - revendikasies tot opneming en gelykberegtiging in die sosiale en geestelike orde van 'n polis wat sy politieke betekenis reeds ingeboet het - 'n filosofie verkondig wat die Herakleitiese Al-logos, die gelykheid van alle mense weens hulle partisipasie aan dieselfde logos en die agrafos nomos of die ongeskrewe universele natuurreg as essensiële leerstukke voordra. Maar dit voer my reeds buitekant die bestek wat ek vir myself afgebaken het.

By wyse van afsluiting mag ek derhalwe konkludeer dat om geskiedenis te wees, die geskiedenis van die filosofie op sy beurt nie bloot moet konstateer wat is of met ander 
woorde watter filosofiese denkbeelde hulle verskyning op die verskillende tydstippe van die Griekse geestesontwikkeling gemaak het nie, maar ook ons in die mate van die moontlike en die bereikbare moet leer waarom daardie denkbeelde ontstaan en ingang gevind het. Hierdie „waarom" word ons met uiterste seldsaamheid in die bewaarde sistematiese brokstukke self aan die hand gedoen. Die sistematiese struktuering van die filosofiese denkbeelde mag die werk van die dialektiese ratio wees en miskien ook geuees het van die oomblik af dat die filosofie self as tematiese problematiek daar is. Maar die verklaring waarom dit daar is, kan nooit deur ratio en dialektiek alleen agterhaal word nie. En die historiese doigté bestaan daar presies in om te verstaan hoe en waarom die gedagtewêreld wat die ratio tot 'n harmonies sluitende geheel deur sy werk van logiese sistematisering wil omskep ontstaan het sowel in die gees van die individuele denker as in die ideësirkulasie van ' $n$ bepaalde tydsgewrig. Laasgenoemde is nie meer die werk van die ratio nie, maar wel die werk van die positiewe geskiedenis. Die geskiedenis van die uysbegeerte behoort derhalwe op twee vlakke gelyktydig te beweeg: op die vlak van die geskiedenis om te leer waaruit die gedagtewêreld van die denkende mens ontspruit en op die logiese vlak van die ratio om te leer hoe dieselfde denkende mens sy denkbeelde in die keurslyf van 'n sistematiese ordening aan die hand van logika en dialektiek dwing. Sonder hierdie laaste is daar miskien nie filosofie nie, maar sonder die eerste is daar ongetwyfeld nie geskiedenis nie.

H. J. de Vleeschauwer.

Pretoria. 